\title{
Systematic Approach to Teaching English Nouns in The Context of Private English Course Classroom Instruction
}

\author{
Azwar Abidin \\ Fakultas Tarbiyah dan Ilmu Keguruan IAIN Kendari \\ azwar.iainkendari@gmail.com
}

\begin{abstract}
Vocabulary knowledge is a crucial component of successful language classroom instruction since all the main aspect of language teaching especially in second and foreign language classroom is depending on vocabulary mastery. In that case, the vocabulary instruction holds a crucial part that the teacher should pay a careful attention to make sure that the students learn the meanings of many words so they can communicate effectively and achieve academically. This research applied descriptive qualitative research to describe private English course instructors' attitude toward teaching vocabulary through systematic approach and their students' response. The researcher took notes while the classroom instruction took place and recorded the whole classroom interaction. By the end of the class, the researcher interviewed and transcribed theirexperience. The findings concluded that the instructors found this systematic approach was easy to implement and the students were engaged more in classroom activities. Over $75 \%$ of the students got excellent scores and they collected most of their points from the items which dealt with combining roots and affixes, identification of the meanings of those roots, and also identification of kinds of derived nouns whether it is personal (actor) or conceptual (action/ thing). Moreover, for about $85 \%$ of them have stated that the activities in the systematic approach in teaching English nouns were enjoyable.
\end{abstract}

Keywords: systematic approach, english noun, classroom instruction, english private course 


\section{Introduction}

Vocabulary mastery is a must qualification to reading comprehension (Susanto \& Suhardianto, 2018) and its importance determines overall language classroom success (González-Fernández \& Schmitt, 2019). Effective vocabulary instruction requires educators to intentionally provide many rich, robust opportunities for students to learn words, related concepts, and their meanings (Dickinson et al., 2019). Students need strong instructional opportunities to build their personal warehouse of words, to develop deep levels of word knowledge, and acquire a toolbox of strategies that aids their independent word acquisition (Oczkus, 2018).

The current trends in English Nouns teaching focus on semantic or meaning-based knowledge (Hedgcock \& Ferris, 2009). The instructors stressed on lexical knowledge by referring the target words they teach to the things that the students found in every day experience. The way the instructors accelerate English Nouns acquisition is by focusing on one word and then build up a brainstorming cloud of ideas from that word. This trial results a better comprehension by fixing errors that were rooted in semantic rather than paying more attention to phonological aspects of English Nouns instructions (Arias de la Cruz et al., 2019). This English Nouns instruction may sometimes need reinforcement through multimedia aid such as storybooks in which it was claimed to help students assess the meaning of words within the context.

English Nouns teaching should be varied and combined according to the students' needs and preferences (Adger et al., 2018). Rivers added that new information must be integrated with the learned foreign language Nouns in order to ease the students notice the reference of the word they are trying to acquire (Rivers, 2019:66). He proceeds to explain that the positive examples in that case, enriched English Nouns teaching with necessary feature of the concept from the target word and ignored the unimportant abstraction from it. The word person, for instance, the learner attached to it some features of being a person such as to be human being, sometimes adult, skin color, age, cultural background, and ignored that person's view, political interest, family hierarchy because it is considered irrelevant, abstract, and unimportant.

In the other hand, Rivers also proposed negative examples in addition to those positive examples (Rivers, 2019:245). This means that the target word is no longer consider its essential features but it is more about the things to which the word does not apply. In the concept of person, for instance, will be attached to the things which are not persons. However, 
these negative examples will be very useful to clear the boundaries of a concept and possibly help the students to distinguish the word from other similar concepts. For example, the word desk and table are semantically related in English. Both concepts involve a flat surface resting horizontally on vertical (usually four) axes. The two words are distinguished in English with respect to the use to which they are put. A table issued for eating from and a desk is used for study (Carr, 2019).

Rivers's systematic approach to teaching English Nouns started by choosing the target word then developed the concept of that word by relating it to other words with similar concepts and attaching it to its features. In fact, some studies such as Kissling et al. (2018) and Newton et al. (2018) show that this approach benefits the foreign language students more. However, any approach has its own advantages, rather than developing concepts of the learned word by connecting it to other related words, it is better for the teacher to boost up students' mastery of English Nouns through morphemic analysis. The morphological approach concerns how the words are referred to particular meanings by analyzing its meaningful parts or what so-called morphemes. The meaning of a word can be modified by its formation in which generally through two ways; inflection and derivation. Plag (2003:180) stated that derivation in one hand takes a word, changes it to another word, and therefore creates a new lexical entry. In the other hand, inflection produces other forms of the same word so it never changes a word to another word and also never changes syntactical category. As a matter of fact, the majority of English Nouns have been created through the combination of morphemic elements such as affixes with base words and word roots.

\section{Systematic Approach to Teaching English Nouns}

The systematic approach to teaching English Nouns can be through investigating a word by paying a careful attention to its inflectional and derivational process. The inflectional process, in one hand, is the manifestation of grammatical relationships through the addition of inflectional prefixes and modification. Inflectional affixes such as number (as in apples and classes), person (as in speaker), finiteness (as in talk and talks), aspect (as in strongest) and case (as in Anne's), which do not change the grammatical class of the stems to which they are attached (Sadler et al., 2018).

The derivational process, in the other hand, is the process of deriving a new word when affixes are added to another morpheme which is popularly 
called root. Derivational affixes have not only independent lexical meaning but also affective meaning. Derivational morphemes are commonly subdivided into prefixes and suffixes. Affixes before the word are called prefixes; those after are called suffixes. Both prefixes and suffixes can be grouped according to linguistic origin and productivity (Dupanović, 2019). Prefixation is the formation of new words by adding prefix or combining form to the base. Prefixes modify the lexical meaning of the base. They do not generally alter the word-class of the base. In Grammar of Contemporary English, the major living prefixes are classified into the following eight categories by their meaning; (1) negative prefixes: un-, non-, in-, dis-, a-, (2) reversative prefixes: un-, de-, dis-, (3) pejorative prefixes: mis-, mal-, pseudo-, (4) prefixes of degree or size: arch-, super-, out-, sub-, over-, under-, hyper-, ultra-, mini-, (5) prefixes of attitude: co-, counter-, pro-, anti-, (6) locative prefixes: super-, sub-, inter-, trans-, (7) prefixes of time and order: fore-, pre-, post-, ex-, re-, (8) number prefixes: uni-, mono-, bi-, di-, tri-, multi-, and poly-. Suffixation is the formation of a new word by adding a suffix or a combining form to the base, and usually changing the word-class of the base. Suffixation is classified to; (1) noun-forming suffixes, (2) adjective-forming suffixes, (3) verb-forming suffixes, and (4) adverb-forming suffixes. Some of most productive suffixes in current English are; -able, -er, -in, -ish, -ize, -y, and-ese (Rensky et al., 1974).

Affixation itself is one of the most productive ways of word building throughout the history of English. Affixation is generally defined as the formation of words by adding derivational affixes to different types of bases. Derived words formed by affixation may be the result of one or several applications of word-formation rule and thus the stems of words making up a word-cluster enter into derivational relations of different degrees. The zero degree of derivation is ascribed to simple words, i.e. words whose stem is homonymous with a word-form and often with a root-morpheme, for instance the English Noun meaning. Derived words whose bases are built on simple stems and thus are formed by the application of one derivational affix are described as having the first degree of derivation, for instance; meaningless. Derived words formed by two consecutive stages of coining possess the second degree of derivation, for instance; meaninglessness.

The importance of affixes, and the need for mastering them, is based on the fact that change has been taking place in life. The need of users of a language also change and this creates a challenge for the language to cope with the needs of the society. Word derivation is one of 
the main processes in using prefixes and suffixes in the English language. Students of English must learn how to use prefixes and suffixes in their correct form. Therefore, it is helpful for students of English to understand the word building process. Newton et al. (2018) maintains that as students advance in their study of the foreign language, they must continue to build their vocabularies. Knowing the area of his weakness, the student can rightly proceed towards this target.

\section{Methods}

This research applied descriptive qualitative analysis to describe instructors' attitude toward teaching vocabulary through systematic approach and their students' response. The research instruments were notes and audio recording. Notes were taken in the middle of instructions take place. Instructors' performance in the teaching and learning process was the main attention. Notes also concerned responses from the students in teaching and learning process as well as their performance inside the classroom. The audio recording was focused on the interview with the instructors after the classes were over. The recorded audio was transcribed into written form manually by using headphone and computer-based audio player. The participants of this research were two English instructors in private courses which in this case work for JILC Pandang-Pandang Kab. Gowa. They are chosen randomly as volunteers to teach English nouns based on systematic approach to the English language learners who are registered formally in JILC private course. The whole process of implementing systematic approach in teaching English Nouns took two months, started from $20^{\text {th }}$ November 2018 to $18^{\text {th }}$ January 2019.

\section{Findings}

The findings of the research cover the description of the result of the data collected through direct learning observation and interviews. Direct learning observation data obtained by the researcher based on checklist of observable items form, any notes, and instructors' attitudes toward systematic approach in teaching vocabulary.

\section{Instructors Attitudes Toward Systematic Approach in Teaching English Nouns.}

Before the class started, the researcher took three meetings with the instructors as they found the approach was never be applied before. 
Unfortunately, the instructors seemed to have a little understanding about the materials. They claimed that the morphological processes had never been taught inside the classroom. However, they were very welcome to this and feeling ready to apply the materials which was packaged into a handout.

The class was started by noticing some English nouns which shared the same root. The instructors presented it in a paragraph. So the paragraph contained some derivations which came from the same root. The instructors wrote the paragraphs on the whiteboard. Paragraph I:

The aquarium where Ahmad puts his fishes is so wonderful. It has many beautiful accessories. The fishes live together with other aquatic livings. Ahmad also puts floral background instead of sea panorama. He said it was the idea of his mother who is a florist. In fact, his mother has panoply of paintings around their house.

Paragraph II:

People, generally, address doctor as the profession specialized in dealing with diseases and troubles. In fact, there are some terms addressing the specialty of the doctor. Such as dermatologist who deals with dermatitis, cardiologist who deals with cardiovascular, orthodontist who straightens human teeth, and orthopedist who straightens human bones. However, whatever the people address them, being a doctor is a noble profession.

The researcher found the students who joined the class could not notice all derived nouns. The instructors had already stressed the pronunciation of those nouns while reading it aloud in front of the class but it could not help. The instructors then underlined the nouns that share the same root such as aquarium, aquatic, florist, panorama, and panoply. The instructors explained the derived words in pair. They explained the meaning of the derived nouns first before attended to their roots. Some examples were given; the words aquarium and aquatic shared the same root aqua. The instructors gave clues by telling the students their meanings in Indonesian; aquarium means palung ikan and the word aquatic means makhluk yang hidup di air. The students were starting to notice that those words related specifically to the water. They, at least, understood the word aqua means air in Indonesian.

The instructors also mentioned the other words of floral and florist. The word floral shares the same root of flor with the noun florist but it is, in fact, an adjective. Some students mentioned the meaning of the word florist in Indonesian as tukang bunga. However, they failed to notice its pair; floral. The 
instructors then wrote on the whiteboard that both of them came from the word flor means flower or bunga in Indonesian. The instruction proceeded to the rest of the words such as panorama (pemandangan sekitar) and panoply (koleksi lengkap) which derived from the word pan means all (semua in Indonesian).

The students regarded the second paragraph as entirely exciting. In fact, that was the first time they know about the terms. The instructors felt the need to explain the meanings of the roots to what the words stood for. The instructors wrote the meanings of those roots in Indonesian such as the root derm as in dermatologist and dermatitis means kulit, the root cardio means hati so the word cardiologist means dokter spesialis organ hati and the word cardiovascular means menyangkut masalah organ hati dan urat nadi. The instructors also wrote the root word ortho which derives orthodontist and orthopedist means lurus in Indonesian. The instructors then mentioned some words that the students missed its roots in their everyday life such as artist (pekerja seni) and artistic (bernilai seni) which were derived from art (seni), polygon (bentuk dengan banyak sisi) and polygamy (punya banyak istri) which were derived from the word poly (banyak), or octave (bait delapan suara), octopus (gurita, dengan delapan tentakel), october (menurut kalender Romawi merupakan bulan ke delapan) which were derived from the word oct/ octo means delapan in Indonesian.

The instructors proceeded to ask the students to write down their own nouns which share the same root on a piece of paper. After that, the students were told to put those nouns in relevant sentences. Some students found that very difficult but there are two of them were showing their writings. They wrote the nouns biology and biography which derived from the word bio and the nouns dentist and dental which derived from the word dent. They were also successful to put those nouns in relevant sentences. When the instructors asked them the meanings of their nouns, they mentioned that the word bio means hidup and the word dent means gigi in Indonesian.

The researcher gave two explanations of an inflectional process which somewhat related to the grammar and a morphological process of which one word can possibly transform into many words. The researcher put examples to an inflectional process of how the third person modifies its verb in present form by adding suffix $-\mathrm{s}$ or es as in Ali does not go to school at Sunday and The teacher explains the materials very well. The researcher also helped the instructors to explain how root can possibly transform into many words and how we recognize the pattern of its transformation along with its meaning. The 
researcher wrote root word teach and explained by adding suffix -er the word becomes teacher and the suffix -er means actor (pelaku). Besides, the root word teach can also transform into the word teaching and the suffix -ing means action/ activity. At the end of the class, the instructors gave students homework contained root words where the students were asked to give its actor and action forms.

In the third meeting, the instructors began to explain the core of the materials. The instructors stressed on the process the affixation which in this case prefixation and suffixation. The researcher found that the students were feeling inconvenience with the terms specifically for pejorative prefixes, reversative prefixes, and prefixes of attitude. After all, the instruction ran well at overall till the end of the program.

\section{Instructors Responses Toward Systematic Approach in Teaching English Nouns}

This part elaborates how the instructors respond to the application of systematic approach in teaching noun to the students inside their classrooms. The responses were documented through direct interview. The researcher prefers to write down the points of the interview intended by the instructors based on the given questions.

The first question the researcher asked was What do you think about the systematic approach in teaching vocabulary? The first instructor was not quite sure about this approach could be applied in his classroom. He claimed by the time the researcher came to him was his first time with the approach. However, he noticed that the approach was somewhat related to morphological processes of the words. He stated that he ever had a course about this in his undergraduate level. The researcher found that the first instructor was very interested in this approach although he did not sure to apply it well inside the classroom. He said that there must a moment in the classroom where students should think about what they have got from the class but they, incidentally, have missed to learn. The second instructor could not agree more with the first instructor. She confidentially claimed that this approach could help her to explain the materials clearly and in more details. She assumed that word classification could be easily identified by using this approach. After all, her students might link it to the previous materials which were given before this approach was applied to strengthen their knowledge. 
The second question was Is the handout helpful enough to support your teaching? The first instructor seemed quite passionate to get the chance of introducing this approach in his teaching activities. Especially, the chance to recall his prior knowledge about the patterns of words formation through the handout. He stated that the handout is an essential tool for the teachers to get any instruction inside the classroom successfully done. Nonetheless, he struggled in many hours to study the handout before confidentially brought the materials into his classroom. The second instructor also agreed with this by means that her instructions inside the classroom could be more strategically structured. She also explained that her students could go back to the previous session in the handout whenever they found something unclear without making her confused.

The third question was Is there any difficulty in applying this approach inside the classroom? The first instructor claimed that the application of this approach was not so difficult. The problem is his own understanding of the approach. Moreover, his understanding of the materials which were developed based on this approach. He stated that in order to successfully apply this approach he should read more and study related relevant references. The second instructor also claimed that she found no difficulties in applying this approach because the instructions were so obviously clear.

The fourth question was How your students respond to this approach and its materials? The first instructor was not quite sure that his students would have a good attitude to this approach especially on the given materials. The students, on the contrary, found the materials were really helpful to assist their knowledge they gained from their formal school. At least, the given materials had significantly changed the way they read and identify the English words from any reading or conversation they heard on TV/ movies. The instructor claimed he nearly gained the goal of this teaching since most of his students could systematically identify the components of the sentences. By means, for instance, how the subject/ actor and his doing/ action could be identified just to pay a little attention to its suffixes and many more. The second instructor claimed that her students had a good response toward this kind of approach. Her students were just feeling motivated ever than before because they had a chance to experience a new way of learning. The materials, as she claimed, assisted them more to identify the word classification in a simple way. This approach changed 
the way they think that learning vocabulary, especially the identification of kinds of nouns in readings was not too difficult after all.

The last question was Do you think the given tests based on the given materials is difficult to your students? The first instructor said no. He claimed that if the test was so difficult then students would keep complaining. In fact, as he claimed, they did not. He believed that the items of the test were also fair enough in number and difficulty. The second instructor also felt confident that her students could complete the given test. She told the researcher that was a certain output since her students found no problems while dealing with the materials before the test was carried out.

\section{Students Preferred Activities of Systematic Approach in Teaching English Nouns}

These data were obtained through the student's checklist form. The researcher putted one question along with student's final evaluation items that specifically asked what was the most preferred activity according to the students. In overall, the following diagram will show the value of each activity:

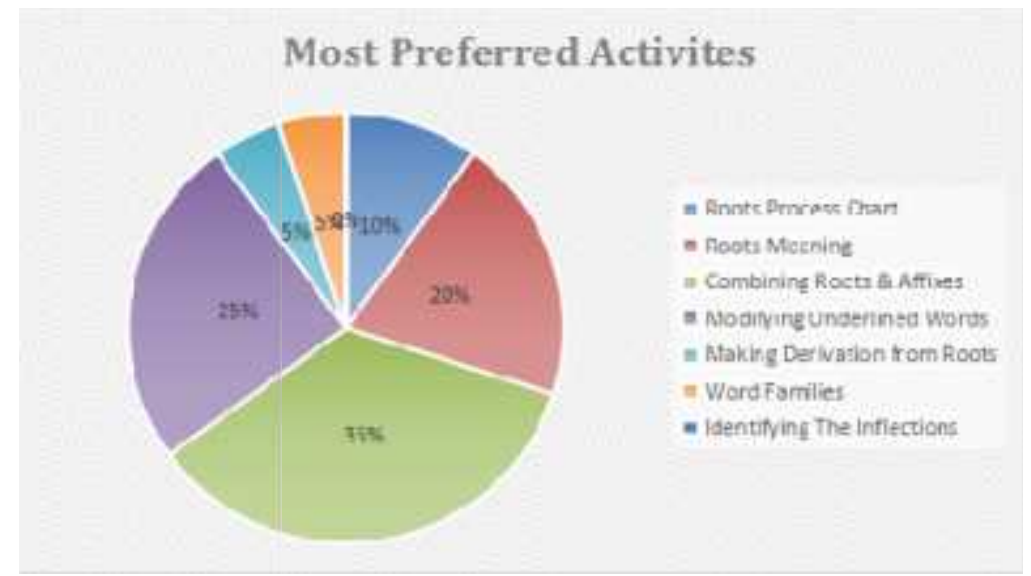

Chart 1; Students' Most Preferred Activities

The previous diagram shows that the most preferred activity by the students was Combining Root and Affixes activity. Seven from the total twenty students had chosen this activity. This makes sense that the students really interested to the systematic approach in teaching English Nouns. The pattern of word formation interested students' curiosity in understanding how the process could possibly be done. The researcher also found that the 
students really fascinated by the alternative ways the systematic approach introduced that enabled them to easily notice the classification of words and especially, nouns. That was because it helped them much to understand the reading materials in just a few steps.

The second most preferred activity chosen by students was Modifying Underlined Words activity. There were five students who claimed this. It can be said that, at overall, students enjoyed the learning program since they engaged themselves in the activity of identifying the noun derivation from roots. This claim can be well supported by the third most preferred activity, Roots Meaning. Curiosity, as the researcher had claimed, was the key to explain this. Students were feeling comfortable to learn either individually or in group as the systematic approach lead them to the simple way of learning English Nouns. By the time the researcher observed the classroom activities, the researcher found that students were fascinated to identify subject or actor from the reading materials just by looking at their suffixes such as those words which end with -er, -or, or -ist.

The next most preferred activity chosen by the students was Roots Process Chart activity. There were only two students had chosen this activity as their favorite. The level of item difficulty caused the students did not interested too much in this activity. However, although the activities presented along the learning program might be very interesting, some students found themselves hard to understand several particular materials. Especially for the derivation process of how some roots match only particul araffixes and mismatch the others. For instance, the students were confused by the affixes that refer to the actor about what verbs that might be attached by -er, -or, or ist and what verbs that might be modified by -ment, -ion, or -ness to form nouns of a kind of action or thing.

The last three activities: Making Derivation from Roots, Word Families, and Identifying Inflections might be resulted from the previous problem. The given materials might beyond their level. However, the students were really enjoying the activities so the researcher found the instructors confidentially continued the learning according to the given handout till the end of the program.

\section{Students Achievement After Joining The Learning Program}

The learning program of systematic approach in teaching English nouns startedfrom $20^{\text {th }}$ November 2018 to $18^{\text {th }}$ January 2019. So it took two months to complete the learning program. At the end of 
the program, the students took the test which items purposely developed according to the given materials.

The test contained ten items. Each item, has ten points if it was answered completely and correctly. The points collected by the students per item is shown in the following chart:

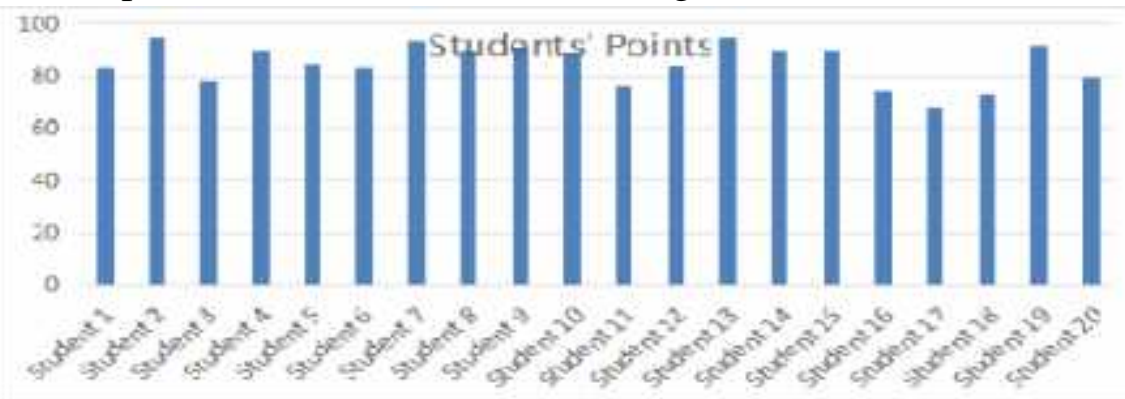

Chart 2. Students' Points from Test Items

There were $45 \%$ students who collected in around 90 points, $30 \%$ students who collected in around 80 points, $20 \%$ students who collected in around 70 points, and only $5 \%$ student who collected points below 70 points. The chart shows that students' achievement in learning program of systematic approach in teaching English nouns was indeed satisfying. All students passed the given test in which $75 \%$ of them got excellent score.

Moreover, the distribution of students' points per item of the test is therefore shown in the following chart. The distribution of the test points will show which item from the test that the students gained most of their points. The items which the students gained most of their points will also indicate which part of learning program that successfully worked. The collected points may indicate students' mastery of particular materials in the learning program.

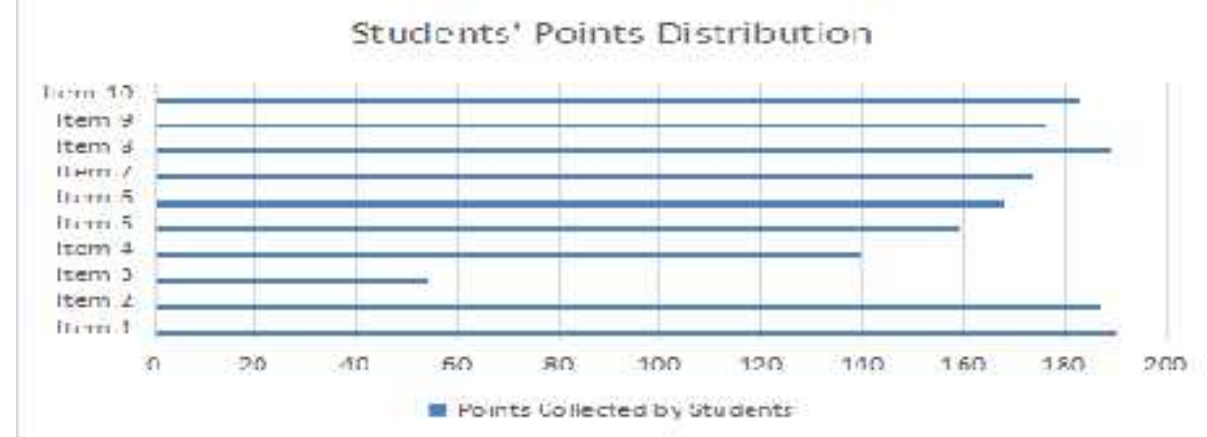

Chart 3. Students' Points Distribution 
The chart shows that item 1 is the most contributed item to the students' points followed by item 8 and item 2 . It is clear now that the students were encouraged to learn English nouns formation through Combining Root and Affixes activity. Students were motivated to identify more roots from derived words. This also lead to the claim that the students were starting to understand the pattern of the word formation including differentiation of nouns that refer to the actor and nouns that refer to the action or thing. This claim was supported by the fact shown in the chart where the next two most contributed items to the students' points were item 8 and item 2. Item 8 contained activity that asked students to form nouns by adding proper affixes to the selected verbs and adjectives as written in the test paper based on their kinds; personal nouns and conceptual nouns. Item 2 asked the students to modify the underlined words by adding or removing affixes according to the given context in the sentence. Most of the students were successfully completing the task.

\section{Students Responses Toward Systematic Approach in Teaching English} Nouns

The data were taken from the student's checklist forms. These checklists were distributed at the end of the program. The checklists contained 5 (five) items in which the students were asked to check whether they agree or not. The first item from the checklist asked the students whether they have the activities and materials of the like before or not. All students claimed that they never found activities and materials like this before. The second item from the checklist asked the students whether they enjoy the activities or not. There were $85 \%$ of them agreed. They felt comfortable to engage in the activities to the end of the learning program. The third item asked the students whether the instructors' explanations were clear or not. There were $95 \%$ of the students found the instructors' explanations were clear enough and easy to understand. Instructors' explanations were undoubtedly an essential factor that would bring success to this learning program. The fourth item from the checklist asked the students whether the given examples were appropriate or not. There were 90\% of the students agreed with this statement. The instructors' explanations were found clear and the given examples must be included in it.

The researcher found that students have successfully presented correct examples in their answers when the test was carried out. The last item from the checklist asked whether the students understand the materials so easily or not. There were $90 \%$ of them agreed that the given materials were easy to understand. This may support the previous claim 
that the instructors had successfully applied this approach in their classroom and the fact that the given examples were appropriate was relevant to this claim of the given materials which were, indeed, easy to understand.

\section{Discussion}

It has been suggested by Graves et al. (2018) that using contextual approach to instruction provided greater vocabulary gains compared with lessons that emphasized learning word definition. The systematic approach which introduced the pattern of word formation and stressed on word especially root definition have shown a large gains and contributed significantly to the students' understanding of English vocabulary especially nouns. The result of this research had shown that the students' curiosity was encouraged by the activity of identifying roots of derived words.

The systematic approach in teaching English nouns also facilitates interactive learning activities. It also supports instructorsstudents dialog in which throughout the learning program, the instructors actively guided their students theoretically and practically. This findings supported the notion of Portes et al. (2018) that vocabulary instructions should include intensive dialog between teachers and students and also promote interactive activities inside the classroom. The findings of this research strengthen the notion of (Gibson, 2018) in which vocabulary its concepts were reinforced through students reworking and hands-on activities. Unlike Gibson, the instructors in this research utilized sheets for students to rework the examples which were given in the middle of instruction and looking-up definition activities.

The systematic approach in teaching English nouns also engaged students in activities that allowed them to use and think about word meanings and then create relationships among those words. The findings of this research as presented in the previous session supported in the same way of intentional vocabulary teaching which was suggested by Portes et al. (2018). Both approaches, systematic and intentional, developed students' awareness of word-level based vocabulary instruction. The systematic approach, otherwise, presented more detailed steps in the learning plan where the instructors were required to deepen their understanding of the word formation before setting up the activities. 


\section{Conclusion}

This research reveals that teaching English nouns to the private course classrooms by using systematic approach is indeed effective. The findings concluded that the students were curiously engaging in the activity of combining roots and affixes and it motivated them more to join the learning program. The students made significant gain in their English nouns learning in which all of them had successfully passed the test which was developed based on the systematic approach materials. Over $75 \%$ of the students got excellent scores and they collected most of their points from the items which dealt with combining roots and affixes, identification of the meanings of those roots, and also identification of kinds of derived nouns whether it is personal (actor) or conceptual (action/ thing).

Moreover, for about $85 \%$ of them have stated that the activities in the systematic approach in teaching English nouns were enjoyable. This study suggests the following items: (1) the instructors of English, especially who work for private course, better consider systematic approach to teaching English nouns to make learning more creative but covers the standard competence of vocabulary instructions, (2) the instructors of systematic approach in teaching English nouns should always check students' understanding to make sure the learning targets could be achieved perfectly, and (3) The materials which deal with systematic approach have not been developed well. So it would be a great idea for English teachers and instructors to seriously take part and give contribution to this.

\section{References}

Adger, C. T., Snow, C. E., \& Christian, D. (2018). What Teachers Need to Know About Language (2nd.). CAL Series on Language Education. https://files.eric.ed.gov/fulltext/ED482994.pdf

Arias de la Cruz, A., Domínguez Barrera, G., \& Morales Vázquez, E. (2019). Form-focused instruction (FFI) and language features attended to during content-based instruction (CBI) lessons at a southeastern Mexican university. Actualidades Investigativas En Educación. https://doi.org/10.15517/aie.v19i1.34785

Carr, P. (2019). English phonetics and phonology: An introduction. John Wiley \& Sons.

Dickinson, D. K., Nesbitt, K. T., Collins, M. F., Hadley, E. B., Newman, K., Rivera, B. L., Ilgez, H., Nicolopoulou, A., 
Golinkoff, R. M., \& Hirsh-Pasek, K. (2019). Teaching for breadth and depth of vocabulary knowledge: Learning from explicit and implicit instruction and the storybook texts. Early Childhood Research

Quarterly. https://doi.org/10.1016/j.ecresq.2018.07.012

Dupanović, E. (2019). Class-Changing Prefixes in the English Language. DHS-Društvene $i$ Humanističke Studije: Časopis Filozofskog Fakulteta u Tuzli, 8, 73-88. https://www.ceeol.com/search/article-detail?id=766542

Gibson, C. (2018). Strengthening Students Mechanics Knowledge through Instructional Videos of Hands-on Activities. Proceedings of the Canadian Engineering Education Association (CEEA).

https://ojs.library.queensu.ca/index.php/PCEEA/article/view/130 66/8377

González-Fernández, B., \& Schmitt, N. (2019). Word Knowledge: Exploring the Relationships and Order of Acquisition of Vocabulary Knowledge Components. Applied Linguistics. https://doi.org/10.1093/applin/amy057

Graves, M. F., Ringstaff, C., Li, L., \& Flynn, K. (2018). Effects of Teaching Upper Elementary Grade Students to Use Word Learning Strategies. Reading Psychology, 39(6), 602-622. https://doi.org/10.1080/02702711.2018.1496503

Hedgcock, J. S., \& Ferris, D. R. (2009). Teaching readers of English students, texts, and contexts. In Teaching Readers of English Students, Texts, and Contexts (2nd ed.). Routledge. https://doi.org/10.4324/9780203880265

Kissling, E. M., Tyler, A., Warren, L., \& Negrete, L. (2018). Reexamining por and para in the Spanish foreign language intermediate classroom: A usage-based, cognitive linguistic approach. In What is Applied Cognitive Linguistics? https://doi.org/10.1515/9783110572186-009

Newton, J. M., Ferris, D. R., Goh, C. C. M., Grabe, W., Stoller, F. L., Vandergrift, L., Newton, J. M., Stoller, F. L., Grabe, W., Vandergrift, L., Goh, C. C. M., \& Ferris, D. R. (2018). Teaching Language Skills in EAP Contexts. In Teaching English to Second Language Learners in Academic Contexts (pp. 1-6). Routledge. https://doi.org/10.4324/9781315626949-1

Oczkus, L. D. (2018). Reciprocal Teaching at Work (3rd ed.). ASCD. 
https://books.google.co.id/books?hl=id\&lr=\&id=C_1lDwAAQB AJ\&oi=fnd\&pg=PP1\&dq=Reciprocal+Teaching+at+Work:+Pow erful+Strategies+and+Lessons+for+Improving+Reading+Compr ehension.\&ots=WIHYO80wWL\&sig=3ENhqF0_Ua4Bk33mhlB coLHtvxI\&redir_esc $=\mathrm{y} \# \mathrm{v}=$ onepage $\& \mathrm{q}=$ Reciprocal

Plag, I. (2003). Word-formation in English. In Word-Formation in English. https://doi.org/10.1017/CBO9780511841323

Portes, P. R., González Canché, M., Boada, D., \& Whatley, M. E. (2018). Early Evaluation Findings From the Instructional Conversation Study: Culturally Responsive Teaching Outcomes for Diverse Learners in Elementary School. American Educational Research Journal. https://doi.org/10.3102/0002831217741089

Rensky, M., Quirk, R., Greenbaum, S., Leech, G., \& Svartvik, J. (1974). A Grammar of Contemporary English. The Modern Language Journal. https://doi.org/10.2307/323848

Rivers, W. M. (2019). Teaching Foreign Language Skills Rev Ed. In Teaching Foreign Language Skills Rev Ed. https://doi.org/10.7208/chicago/9780226518855.001.0001

Sadler, L., Nordlinger, R., Sadler, L., \& Nordlinger, R. (2018). Morphology in Lexical-Functional Grammar and Head-driven Phrase Structure Grammar. In The Oxford Handbook of Morphological Theory (1st ed., pp. 211-243). Oxford University Press. https://doi.org/10.1093/oxfordhb/9780199668984.013.17

Susanto, A., \& Suhardianto. (2018). Exploring The Role of Vocabulary Level Test in Batam Student's Comprehension of Textbooks. Khazanah Ilmu Berazam, 1(2), 7-16. http://www.ejournal.ymbz.or.id/index.php/1/article/view/14 